\title{
Excretion of organic chlorine compounds in the urine of persons exposed to vapours of trichloroethylene and tetrachloroethylene
}

\author{
MASANA OGATA, YOSHIKO TAKATSUKA, and KATSUMARO \\ TOMOKUNI (with the technical assistance of KOZUE MUROI) \\ Department of Public Health, Okayama University Medical School, Okayama, Japan
}

\begin{abstract}
Ogata, M., Yoshiko, T., and Tomokuni, K. (1971). Brit. J. industr. Med., 28, 386-391. Excretion of organic chlorine compounds in the urine of persons exposed to vapours of trichloroethylene and tetrachloroethylene. Male volunteers were exposed to 170 p.p.m. of trichloroethylene vapour either for 3 hours or for 7 hours with one break of 1 hour; or to 87 p.p.m. of tetrachloroethylene vapour for 3 hours. Urine was collected frequently up to 100 hours after the start of exposure, and was analysed for trichloroethanol and trichloroacetic acid. After trichloroethylene exposure, trichloroethanol was excreted most rapidly shortly after exposure ceased, and trichloroacetic acid most rapidly 42 to 69 hours after exposure ceased. Total recoveries of trichloroethylene inhaled, up to 100 hours, were: trichloroethanol, after 3 hours' exposure, $53.1 \%$; after 7 hours' exposure, $44 \%$; trichloroacetic acid, similarly: $21.9 \%$ and $18.1 \%$. The effects of exposure on blood pressure, pulse rate, flicker value, and reaction time were measured. The diastolic blood pressure was decreased significantly after 3 hours' exposure to 170 p.p.m. trichloroethylene. After tetrachloroethylene exposure, in 67 hours trichloroacetic acid was excreted to $1.8 \%$ tetrachloroethylene retained and an unknown chloride equivalent to $1.0 \%$.

Urine samples from 10 workers in an automobile parts factory were analysed for trichloroethanol and trichloroacetic acid. Trichloroethanol concentrations in the urine taken after work were higher than in the urine taken before work while for trichloroacetic acid the concentrations were reversed, due to the difference in the time course of excretion. The urinary levels of trichloroethanol, trichloroacetic acid, and total trichloro compounds were almost proportional to the environmental concentration of trichloroethylene.
\end{abstract}

As trichloroethylene is widely used as a solvent, many people are exposed to trichloroethylene vapour during their working day. The urinary concentration of trichloroacetic acid, one of its metabolites, has been suggested as an index of trichloroethylene exposure. Forssman and Ahlmark (1946) and Ahlmark and Forssman (1951) gave $75 \mathrm{mg} /$ litre as the threshold limit value (T.L.V.), as nearly all men with this urinary concentration or higher had complained of symptoms. Frant and Westerndorp (1950) showed that workers inhaling 100 p.p.m. (T.L.V.) of trichloroethylene excreted about $200 \mathrm{mg} / \mathrm{litre}$ of trichloroacetic acid in the urine.

Excretion of trichloroethylene metabolites in the urine of volunteers exposed to trichloroethylene in an artificial exposure chamber was studied by 
Souček and Vlachová (1960), who showed that metabolites were excreted equivalent to about $73 \%$ of the trichloroethylene retained (monochloroacetic acid $4 \%$, trichloroacetic acid $19 \%$, and trichloroethanol $50 \%$ ). They suggested that the excretion of trichloroethanol would also serve as an index of trichloroethylene exposure. The excretion of trichloroacetic acid was slower than that of trichloroethanol.

Tanaka and Ikeda (1968), however, from analyses of urinary trichloroethanol and trichloroacetic acid from human subjects, showed that the ratio of trichloroethanol to trichloroacetic acid varied with the trichloroethylene concentration, indicating that that the best index of exposure was the total trichloro compound excreted. To provide further evidence on this, we have measured the rate of excretion of trichloroethanol and trichloroacetic acid from volunteers exposed singly in an artificial exposure chamber and have reported on the volunteers' symptoms and signs, and in the workshop we have also studied the relationship between the environmental trichloroethylene concentration and urinary trichloroethanol and trichloroacetic acid.

Tetrachloroethylene is used in dry cleaning instead of trichloroethylene because of its lower vapour pressure. The hepatotoxicity, however, of tetrachloroethylene is greater than that of trichloroethylene (Ogata, Tomokuni, and Watanabe, 1968). Yllner (1961) showed that tetrachloroethylene is excreted mostly as trichloroacetic acid, but also as oxalic acid. One of the Fujiwara reaction-positive substances excreted has been shown to be trichloroacetic acid by paper chromatography (Ogata, Sugiyama, and Kuroda, 1962) and by gas chromatography (Ogata and Tomokuni, 1969).

The rate of excretion of trichloroacetic acid and total organic chlorides in the urine of volunteers exposed to tetrachloroethylene has been studied in an artificial exposure chamber, as also were the physiological changes induced.

\section{Material and methods}

Experiments using the exposure chamber

Experiments were carried out on 13 volunteers of average age 34.5 years who were exposed to either trichloroethylene or tetrachloroethylene. For exposure to trichloroethylene (170 p.p.m.) either five people remained in the exposure chamber for 3 hours in the morning and for 4 hours in the afternoon with a break of 1 hour in between, or four people remained in for only 3 hours in the morning. Another four volunteers were exposed to 87 p.p.m. tetrachloroethylene for 3 hours in the morning.

The vapour concentrations in the chamber were determined every half hour by gas chromatography with a flame ionization detector (Hitachi Co. Ltd., K-53) and also by Kitagawa detector tube every 15 minutes. The averages of the concentrations found by gas chroma- tography were taken as correct. They were constant to within $\pm 9.5 \%$.

During the last 2 hours of exposure, the concentrations in the expired air were also determined by gas chromatography. In each experiment, all the urine was collected from each subject for about one week after exposure. The urines of subjects exposed to trichloroethylene were analysed for trichloroethanol and trichloroacetic acid by the methods of Tanaka and Ikeda (1968). Those from subjects exposed for 7 hours were also analysed by the method of Ogata, Takatsuka, and Tomokuni (1970). Metabolites excreted by volunteers exposed to tetrachloroethylene were analysed according to Tanaka and Ikeda (1968). It was difficult to identify trichloroethanol by its absorption spectrum in our method (Ogata et al., 1970). At the beginning and the end of the exposure period the diastolic blood pressure, pulse rate, flicker value, and reaction time were measured as described previously (Ogata et al., 1970).

\section{Experiments in the workshop}

For the determination of trichloroethylene in the air, Kitagawa detection tubes were used. Estimations were made near the nose of each worker every 20 minutes, and the average was taken as the environmental concentration (for 9 hours with 1 hour's break). To determine the time course of excretion, the urines were collected over the periods 6 to 8 a.m., 8 a.m. to noon, noon to 5 p.m., and 5 to 9 p.m. To study the relationship between trichloroethylene concentrations in the air and trichloro compounds in the urine, the urines obtained between noon and 5 p.m. were used. We had already found in preliminary experiments that, for workmen engaged in similar work every day, the concentration of urinary organic chloride reached a steady state by Wednesday. We therefore measured atmospheric trichloroethylene and urinary metabolites on Wednesday. The metabolites were determined as described by Ogata and his colleagues (1970).

\section{Results}

\section{Time course of excretion of metabolites}

Figure 1A shows the hourly excretion of trichloroethanol and trichloroacetic acid in the urine of volunteers exposed to 170 p.p.m. of trichloroethylene for 7 hours with 1 hour's break. Trichloroethanol excretion increased rapidly during the first 3 hours, slowed a little during the break in exposure, and then rose again to a maximum 1 hour after the time the subject left the exposure chamber. By 92 hours later the excretion rate $(\mathrm{mg} / \mathrm{hr})$ had returned almost to normal. Trichloroacetic acid appeared in the urine immediately after the exposure started. Its excretion rate rose slowly, reaching a maximum 42 hours after the subject had left the chamber. By 92 hours later the concentration had almost returned to normal.

Figure 1B shows similar results for subjects exposed to 170 p.p.m. of trichloroethylene for only 3 hours. The maximum rate of excretion of trichloroethanol was attained at 3 hours and that of trichloroacetic acid at 69 hours after the cessation of exposure. 


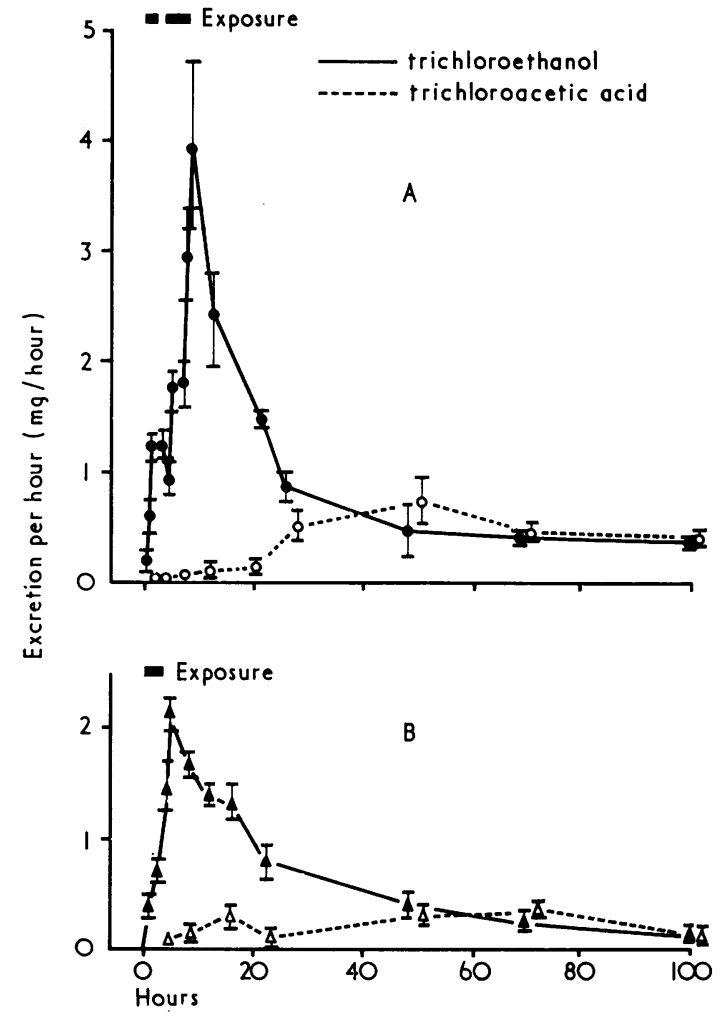

FIG. 1. Urinary excretion rates of trichloroethanol and trichloroacetic acid in the urine of volunteers exposed to 170 p.p.m. trichloroethylene for $3 \mathrm{hr}$ in the morning and for $4 \mathrm{hr}$ in the afternoon with $1 \mathrm{hr}$ break in between (A), and of those exposed only for $3 \mathrm{hr}$ in the morning (B) (mean \pm S.E.M.). The value on the vertical line is shown as one-tenth of the actual value.

Concentrations of trichloroethanol and trichloroacetic acid were determined by direct colorimetric method.

Figure 2 shows the curve for the average excretion rates of trichloro compounds in the urine of volunteers exposed to 87 p.p.m. of tetrachloroethylene for 3 hours. Two trichloro compounds were determined, trichloroacetic acid and a compound which gave trichloroacetic oxidation by chromium oxide. We could not identify the latter as trichloroethanol so we have called it 'unknown chlorinated hydrocarbon'. The excretion of trichloroacetic acid increased until 3 hours from the end of the exposure, and returned nearly to normal 64 hours later. The excretion of the unknown chlorinated hydrocarbon followed a similar course.

\section{Total metabolites excreted}

These were calculated as described by Ogata, Tomokuni, and Takatsuka (1970). Up to 67 hours, trichloro compounds equivalent to $56.7 \%$ of the trichloroethylene inhaled during 7 hours and $70.4 \%$

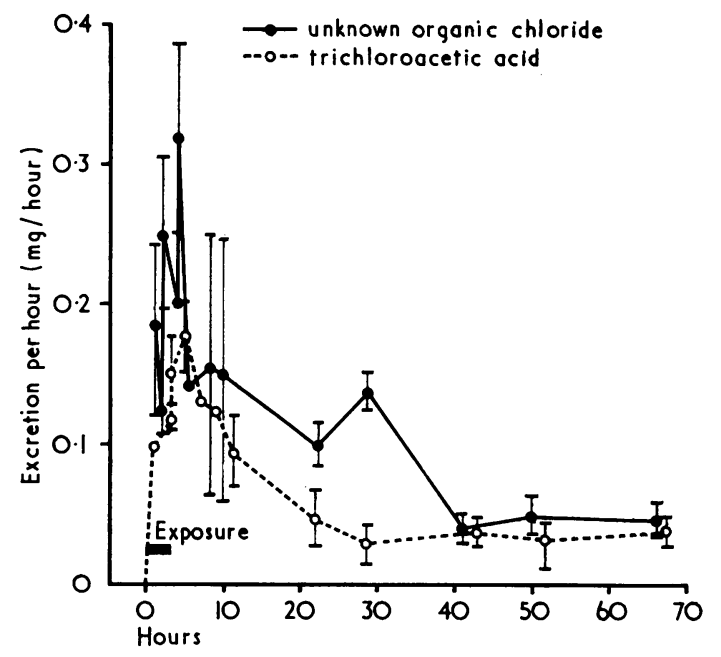

FIG. 2. Urinary excretion of trichloroacetic acid and of an unknown organic chloride in the urine of volunteers exposed to 87 p.p.m. tetrachloroethylene for $3 \mathrm{hr}$ (mean \pm S.E.M.).

The concentrations of trichloroacetic acid and the unknown organic chloride were determined by the chromium oxidation method.

of that inhaled during 3 hours were recovered. By 100 hours, recoveries were $62.1 \%$ and $75.9 \%$ respectively. In 67 hours, trichloro compounds equivalent to $2.8 \%$ of the tetrachloroethylene were recovered.

\section{Relationship between exposure and total metabolites excreted}

The total exposure can be measured in the units p.p.m. $\times$ time in hours. An almost linear relationship was found between the total exposure and the total excretion up to 100 hours after the beginning of exposure (Fig. 3). After tetrachloroethylene exposure total excretion was small, in 67 hours amounting to only about $4.0 \%$ of the metabolites excreted after the inhalation of the same amount of trichloroethylene. Figure 3 also shows that the two methods of estimating trichloro compounds (see materials and methods section) were in good agreement. For calculating the ratio of the metabolites to the trichloroethylene retained, the results obtained by the chromium oxidation method were used, as the excretion of metabolites of tetrachloroethylene was measured in this way.

\section{Effects of exposure on physiological measurements}

The results are shown in the Table. The pulse rate showed no consistent change. The diastolic blood pressure during exposure to 170 p.p.m. trichloroethylene decreased significantly after 3 hours of exposure, and an increase of systolic pressure was 


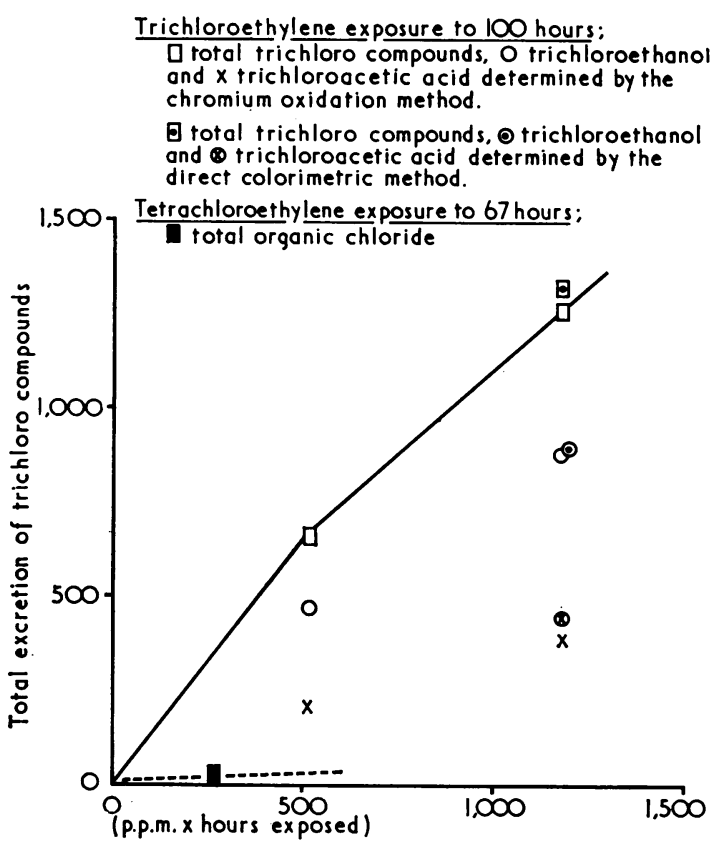

FIG. 3. Relationship between total exposure and total excretion (mg) of urinary trichloroethanol, trichloroacetic acid, and total trichloro compounds. also observed. Exposure caused no consistent change in flicker value or reaction times.

Excretion of trichloroethanol and trichloroacetic acid before, during, and after work by workers exposed to trichloroethylene

Trichloroethanol concentrations in the urine collected after work were higher than trichloroacetic acid concentrations, whereas the converse was true before work (Fig. 4). These determinations were made on a Wednesday, after two days' intermittent exposure. These findings can be explained from the results on subjects in the exposure chamber. They excreted trichloroacetic acid more slowly than trichloroethanol, as already described.

Relation between average trichloroethylene concentration in air and trichloroethanol, trichloroacetic acid, and total trichloro compounds in afternoon urine

Figure 5 shows the linear regression lines obtained. It includes results on non-exposed workers. The equations for the regression lines, with metabolite concentrations corrected to a urine density of 1.024 , are:

Trichloroethanol

$\mathrm{mg}$ trichloroethanol/litre $=5 \cdot 19 \times($ p.p.m. trichloroethylene) $+12 \cdot 28$ $r=0.89$

TABLE

Effect of Exposure to Trichloroethylene and Tetrachloroethylene on Pulse Rate, Systolic and Diastolic Blood Pressure, Flicker Value, and Reaction Time on Subjects in Exposure Chamber

\begin{tabular}{|c|c|c|c|c|c|c|c|c|}
\hline \multirow{3}{*}{$\begin{array}{l}\text { Items } \\
\text { examined }\end{array}$} & \multirow{3}{*}{ p.p.m. } & \multicolumn{4}{|c|}{ Trichloroethylene } & \multirow{3}{*}{ p.p.m. } & \multirow{2}{*}{\multicolumn{2}{|c|}{$\begin{array}{c}\text { Tetrachloroethylene } \\
\begin{array}{c}\text { Morning } \\
\text { (hours' exposure) }\end{array}\end{array}$}} \\
\hline & & \multicolumn{2}{|c|}{$\begin{array}{c}\text { Morning } \\
\text { (hours' exposure) }\end{array}$} & \multicolumn{2}{|c|}{$\begin{array}{c}\text { Afternoon } \\
\text { (hours' exposure) }\end{array}$} & & & \\
\hline & & 0 & 3 & 4 & 7 & & 0 & 3 \\
\hline $\begin{array}{ll}\text { Pulse } & \ldots \\
\text { rate/min } & \ldots\end{array}$ & $\begin{array}{r}170 \\
0\end{array}$ & $\begin{array}{l}76.2 \pm 5.9 \\
89.0 \pm 7.0\end{array}$ & $\begin{array}{l}76 \cdot 2 \pm 13 \cdot 7 \\
84 \cdot 0 \pm 6 \cdot 0\end{array}$ & $\begin{array}{c}82 \cdot 0 \pm 11 \cdot 4 \\
-\end{array}$ & $81 \cdot 6 \pm 12 \cdot 2$ & $\begin{array}{r}87 \\
0\end{array}$ & $\begin{array}{l}56 \cdot 7 \pm 4 \cdot 1 \\
89.0 \pm 7.0\end{array}$ & $\begin{array}{l}68 \cdot 0 \pm 9 \cdot 2 \\
84.0 \pm 6.0\end{array}$ \\
\hline $\begin{array}{c}\text { Systolic } \ldots \\
\text { pressure } \\
(\mathrm{mmHg}) \ldots\end{array}$ & $\begin{array}{r}170 \\
0\end{array}$ & $\begin{array}{l}116.6 \pm 13 \cdot 6 \\
114 \cdot 0 \pm 6 \cdot 0\end{array}$ & $\begin{array}{l}112.0 \pm 4.9 \\
110 \cdot 0 \pm 11.0\end{array}$ & $\begin{array}{c}114 \cdot 8 \pm 10 \cdot 1 \\
-\end{array}$ & $\begin{array}{c}111 \cdot 2 \pm 11 \cdot 1 \\
-\end{array}$ & $\begin{array}{r}87 \\
0\end{array}$ & $\begin{array}{l}122.0 \pm 13.5 \\
114.0 \pm 6.0\end{array}$ & $\begin{array}{l}124.0 \pm 2.7 \\
110.0 \pm 11.0\end{array}$ \\
\hline $\begin{array}{l}\text { Diastolic } \\
\text { pressure } \\
(\mathrm{mmHg})\end{array}$ & $\begin{array}{r}170 \\
0\end{array}$ & $\begin{array}{l}80.2 \pm 6.4 \\
76 \cdot 2 \pm 2.0\end{array}$ & $\begin{array}{l}66.4 \pm 5.2^{1} \\
71 \cdot 0 \pm 9.0\end{array}$ & $\begin{array}{c}69.6 \pm 9 \cdot 7 \\
-\end{array}$ & $\begin{array}{c}66 \cdot 8 \pm 12 \cdot 4 \\
-\end{array}$ & $\begin{array}{r}87 \\
0\end{array}$ & $\begin{array}{l}68 \cdot 3 \pm 11 \cdot 1 \\
76 \cdot 2 \pm 2 \cdot 0\end{array}$ & $\begin{array}{l}83.3 \pm 6.5 \\
71.0 \pm 9.0\end{array}$ \\
\hline $\begin{array}{l}\text { Flicker } \\
\quad \text { value }(\%)^{2}\end{array}$ & $\begin{array}{r}170 \\
0\end{array}$ & $\begin{array}{l}100 \cdot 0 \\
100 \cdot 0\end{array}$ & $\begin{array}{r}108 \cdot 1 \pm 5 \cdot 3 \\
89 \cdot 0 \pm 14 \cdot 0\end{array}$ & $\begin{array}{c}114.4 \pm 3.0 \\
-\end{array}$ & $\begin{array}{c}105 \cdot 7 \pm 2 \cdot 8 \\
-\end{array}$ & $\begin{array}{r}87 \\
0\end{array}$ & $\begin{array}{l}100 \cdot 0 \\
100 \cdot 0\end{array}$ & $\begin{array}{l}89 \cdot 5 \pm 2.4 \\
89.0 \pm 14.0\end{array}$ \\
\hline $\begin{array}{l}\text { Reaction } \\
\text { time } \\
\left(10^{-2} \mathrm{sec}\right)\end{array}$ & 170 & $18 \cdot 4 \pm 2 \cdot 6$ & $18 \cdot 2 \pm 2 \cdot 6$ & $16.2 \pm 4.9$ & $17 \cdot 9 \pm 5 \cdot 2$ & 87 & - & - \\
\hline
\end{tabular}

${ }^{1}$ Difference from controls significant at $5 \%$ level. 'Percentage of value just before exposure. 


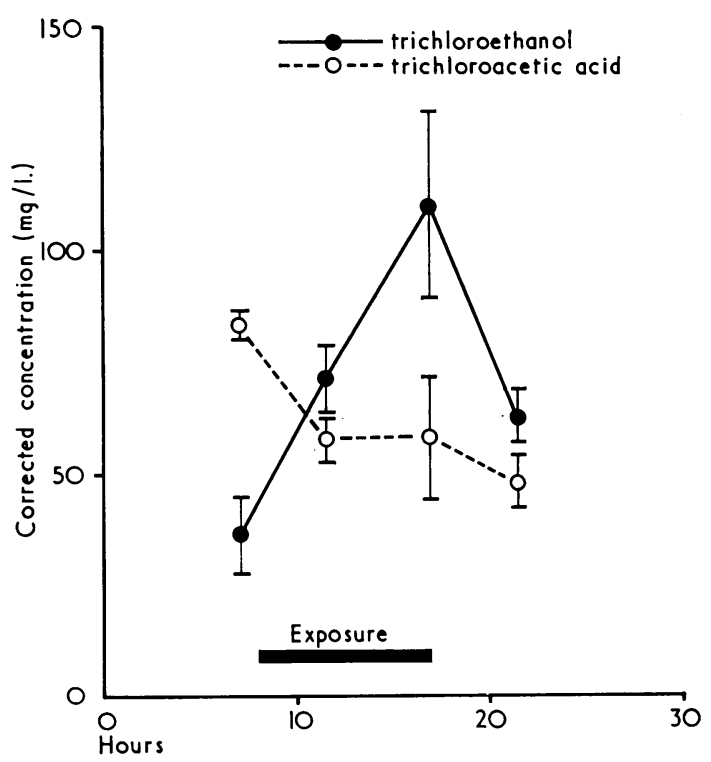

FIG. 4. Diurnal excretion of trichloroethanol and trichloroacetic acid in the urine of workers exposed to trichloroethylene at an automobile parts factory. Excretion was expressed as concentration corrected for variations in the density of urine to density $=1 \cdot 024$.

Trichloroacetic acid:

mg trichloroacetic acid/litre 3.17 (p.p.m. trichloroethylene) $+4 \cdot 84$

$r=0.94$

Total metabolites:

$\mathrm{mg} /$ litre

$$
\begin{aligned}
&= 8 \cdot 37 \text { (p.p.m. trichloro- } \\
& \text { ethylene) }+17 \cdot 12 \\
& \mathrm{r}=0.93
\end{aligned}
$$

From these equations the urinary concentrations of trichloroethanol, trichloroacetic acid, and total trichloro compounds, corresponding to 100 p.p.m. of trichloroethylene (the T.L.V. suggested by A.C.G.I.H.) were calculated to be $531 \mathrm{mg} / \mathrm{l}, 322$ $\mathrm{mg} / \mathrm{l}$, and $854 \mathrm{mg} / \mathrm{l}$ respectively.

\section{Discussion}

In the subjects exposed to trichloroethylene in an artificial exposure chamber the concentration of trichloroethanol in the urine attained its maximum 1 to 3 hours after exposure and that of trichloroacetic acid 42 to 69 hours after exposure. Excretion of both metabolites continued up to 100 hours.

In a workshop, where workers were exposed to trichloroethylene vapour every day, the urinary trichloroethanol concentrations determined after work in the middle of the working week were higher than those determined before work, and the reverse was true for trichloroacetic acid. Thus, excretion of the former was more closely related to exposure on the same day, whereas excretion of the latter was more closely related to exposure on a few previous days. The concentrations of trichloroethanol and trichloroacetic acid in workers' urine were markedly higher than those in the urine of subjects in the exposure chamber when corrected to the same average rate of inhalation. This was because trichloroethanol and trichloroacetic acid excretion continued up to 100 hours and only attained its steady state in workers exposed to trichloroethylene every day; Roach (1966) has discussed this theoretically.

The relationship between the trichloroethylene concentration in the air and trichloroacetic acid concentration in the urine was similar to that described by Frant and Westendorp (1950).

The total excretion in 67 hours from the beginning of exposure' of trichloroacetic acid in the urine of volunteers exposed to tetrachloroethylene was equivalent to $1.8 \%$ of the tetrachloroethylene retained and that in the urine of volunteers exposed to trichloroethylene was equivalent to $70.4 \%$ of the trichloroethylene retained. After exposure to tetrachloroethylene an unknown organic chloride was also excreted. This was converted to trichloroacetic acid after oxidation with chromium oxide. We could not detect the absorption maximum of trichloroethanol after treating with $\beta$-glucuronidase by the method described previously (Ogata et al., 1970), so the organic chloride compound could not

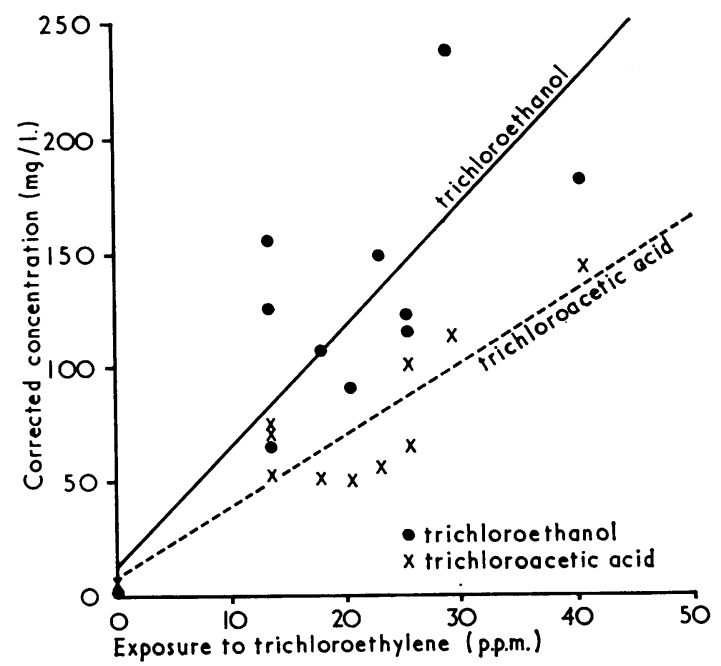

FIG. 5. Relationship between trichloroethylene in the air and urinary trichloroethanol and trichloroacetic acid. Samples were taken in the afternoon.

Symbols corresponding to 0 p.p.m. show average of six non-exposed workers. 
be identified as trichloroethanol. The total excretion of organic chloride of volunteers exposed to tetrachloroethylene was, however, only $2.8 \%$ of the tetrachloroethylene retained, as against $75.0 \%$ of the trichloroethylene retained. This indicates that tetrachloroethylene was eliminated through expiration rather than in urine and that its metabolites are retained for a longer time in the body. Ogata et al. (1968) showed that the increased liver triglyceride and decreased adenosine triphosphate in mice returned more slowly to normal after the inhalation of tetrachloroethylene than of trichloroethylene.

Yllner (1961) found that in mice exposed to ${ }^{14} \mathrm{C}$ tetrachloroethylene vapour for 2 hours $52 \%$ of the total urinary radioactivity was in trichloroacetic acid and $11 \%$ in oxallic acid, and he suggested the formation of an epoxide which was further converted to trichloroacetyl chloride as one of the metabolic pathways for tetrachloroethylene:

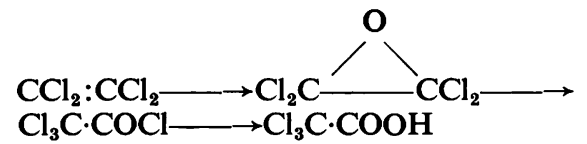

In the present experiment, the maximum rate of excretion of trichloroacetic acid occurred more quickly after tetrachloroethylene than after trichloroethylene, which also suggests a difference in the metabolic pathway followed by the two chlorinated hydrocarbons.

After exposure to trichloroethylene at 1190 p.p.m. $X$ hours the total excretion of trichloro compounds was a little lower than that after 500 p.p.m. $\times$ hours. The effect was not great enough to warrant the conclusion that the metabolic capacity of the pathways begins to be saturated at around 500 p.p.m. hours exposure.

In our subjects, 170 p.p.m. of trichloroethylene produced a decrease in diastolic blood pressure. In contrast, toluene inhalation caused a decrease in the pulse rate and in the systolic blood pressure.

\section{References}

Ahlmark, A., and Forssman, S. (1951). Evaluating trichloroethylene exposures by urinalysis for trichloroacetic acid. Arch. industr. Hyg. occup. Med., 3, 386-398.

Forssman, S., and Ahlmark A. (1946). Bidrag till diagnostiken av trikloretylenförgiftningar. Nord. Med., 30, 1033-1034.

Frant, R., and Westendorp, J. (1950). Medical control on exposure of industrial workers to trichloroethylene. Arch. Industr. Hyg. Occup. Med., 1, 308-318.

Ogata, M., Sugiyama, K., and Kuroda, Y. (1962). Investigation of a drycleaning shop using tetrachloroethylene (with special reference to Fujiwara's substance in the urine of employees). Okayama-Igakkai-Zasshi. (in Japanese), 74, 247-253.

-, Takatsuka, Y., and Tomokuni, K. (1970). A simple method for the quantitative analysis of urinary trichloroethanol and trichloroacetic acid as an index of trichloroethylene exposure. Brit. J. industr. Med., 27, 378-381.

- and Tomokuni, K. (1969). Excretion of toluene, xylene and tri and tetrachloroethylene metabolites in human urine as an index of exposure. Abstracts of 16th Congress of Occupational Health, p. 98.

- , - and Takatsuka, Y. (1970). Urinary excretion of hippuric acid and $m$ - or $p$-methylhippuric acid in the urine of persons exposed to vapours of toluene and $m$ - or p-xylene as a test of exposure. Brit.J. industr. Med., 27, 43-50.

,-- , and Watanabe, S. (1968). ATP and lipid contents in the liver of mice after inhalation of chlorinated hydrocarbons. Industr. Hlth (Kawasaki), 6, 116-119.

Roach, S. A. (1966). A more rational basis for air sampling programs. Amer. industr. Hyg. Ass. J., 27, 1-12.

Souček, B., and Vlachová, D. (1960). Excretion of trichloroethylene metabolites in human urine. Brit. J. industr. Med., 17, 60-64.

Tanaka, S., and Ikeda, M. (1968). A method for determination of trichloroethanol and trichloroacetic acid in urine. Brit. J. industr. Med., 25, 214-219.

Yllner, S. (1961). Urinary metabolites of " ${ }^{14} \mathrm{C}$-tetrachloroethylene in mice. Nature (Lond.), 191, 820.

Received for publication October 28, 1970. 